\title{
Iranian EFL Learners' Perception and Performance of Communication Strategies in Different Mediums of Communication
}

\author{
Asa Moattarian \\ Sheikhbahaee University, Isfahan, Iran \\ Email: a.moattarian@hotmail.com
}

\begin{abstract}
Although language learners spend years developing their competences, they sometimes experience the frustration of not being able to communicate. They have problems in communication mostly due to their insufficient knowledge, but they rely on their ability to communicate within restrictions, using common communication strategies. This descriptive study was set to find out learners' attitudes towards communication strategies and examined areas they vary by medium (oral and written performances), and compared them with their performances. To this end, 100 EFL learners, majoring in English, were selected and asked to fill out a 24 item questionnaire, developed based on Dornyei's taxonomy eliciting their attitudes towards the use of communication strategies in their oral and written performances; later on 60 EFL learners' oral and written performances were analyzed and compared to perceptions. Descriptive statistics showed that the learners' perceptions and performances of communication strategies vary by medium, and some strategies are, generally, used more frequently than others. Moreover, it was revealed that in some cases learners' perceptions and performance are in line with each other, while in some others they are distinct.
\end{abstract}

Index Terms -interlanguage, oral performance, written performance, communication strategies

\section{INTRODUCTION}

Language is defined as "the system of human communication which consists of the structured arrangement of sounds into larger units" (Richards \& Schmidt, 2002, p. 283), hence the ability to communicate is the optimal goal for all language learners, because one knows a language when he understands that language and be understood by the speakers of that language. However, there are always some deficiencies in communication and speakers should try to compensate for the gaps to prevent communication breakdowns; communication strategies (CSs) are useful tools to keep the communication channel open.

The notion of CSs was first introduced by Selinker (1972) in his seminal article entitled interlanguag to talk about some errors in learners' interlangauge. He argued that errors are made due to learners' will to communicate; in fact they want to express themselves by means of their insufficient knowledge of language. A working definition for CSs was suggested by Corder (1981, p103) as "systematic technique employed by the speaker to express his meaning when faced with some difficulty." This definition opened the doors of research to explore CSs closely and systematically, which led to proposing different taxonomies. According to Kongsom (2009), some noteworthy and frequently cited taxonomies are those provided by Varadi (1973); Tarone (1978); Faerch and Kasper (1983); Nijmegen project (1989); Bialystok (1990); and Dornyei (1995).

To the present time a great deal of research has been done to investigate the use of CSs. Ellis (1984) mentioned that CSs can be considered as a good notion for evaluating L2 communicative performance. He emphasized teachers can understand a lot about the learners' knowledge by examining the CSs they employ. Faerch and Kasper (1983) and Bialystok (1990) regarded the use of CSs as cognitive processes in producing sentences when the speakers encounter language deficiencies. Furthermore, Bialystok said that looking at CSs just in surface structure is too simplistic, and to study CSs comprehensively cognitive and psycholinguistic matters must be considered as well (cited in Kongsom, 2009).

Zheng (2004) found that CSs are inevitable in oral communication for language learners, since these strategies keep speakers flexible, and confident, they also make communication more effective. Puffer (2006) mentioned speaking in L2, specially in real life tasks, is very demanding for language learners because they have to think about choice of words, discourse, grammatical points, etc; therefore, they may encounter gaps in their communication; moreover, while writing in second language, language learners encounter difficulties in goal setting, generating and organizing the material to convey the message (Silva, 1993); therefore, there is a need for use of CSs to meet the goal of communication in both oral and written performances.

Research on attitude has been popular in last 50 years, due to increasing interest in relating language to thinking (Saidat, 2010). The importance of beliefs and attitudes has been of great interest for many scholars from different disciplines, in which human behavior and learning are the primary concerns like cognitive psychology, educational 
psychology and social psychology (Gabillon, 2005). Gardners' socioeducational model of language learning (1985) incorporated learners' cultural beliefs, integretiveness, motivation and attitudes into learning a language(cited in Williams \& Burden 1997). This has encouraged researchers to investigate this phenomenon in studies on language learning

Barkhuizen (1998) believed that teachers have to discover learners' feelings and beliefs about their language learning experiences and consequently to review and sometimes even change their teaching activities. Questionnaires are often used as instruments in attitude studies. The questions in such questionnaires are considered as a valuable source in giving a general and comprehensive picture of how people think about that issue.

Baker (1992) opted that in general sense, an attitude is a hypothetical construct aiming at explaining the direction and persistence of human behavior. He also mentioned three major reasons for investigating learners' attitudes "its close connection to individual construct systems, its value as an indicator of viewpoints in the community, and its centrality in psychological theory and research assets to attitude as a central topic."(P.10)

Wei (2011) found out that learners' attitudes has some influence on the use of CSs; EFL learners tend to employ reduction strategies most often and seldom opt for achievement strategies, although they tend to believe the important role of achievement strategies in communication.

Generally it can be concluded that investigating the use of CSs by language learner reveals a lot about the learners' interlanguage; therefore, the present study is set to investigate learners' attitudes towards the use of CSs in their oral and written communication and compare them with their performances; in fact in this study the researcher attempted to answer the following question:

What are Iranian EFL learners' perceptions about CSs, and how are they different from their performances in different mediums of communication?

\section{Methodology}

\section{A. Participants}

as in this study EFL university students' perception and performances were under investigation, 100 Iranian EFL BA level university students, both male and female who shared Persian as their mother tongue, were randomly selected and asked to fill out the questionnaire, and later in the second phase of the study 60 EFL students were asked to accomplish an oral and a written task.

\section{B. Instruments}

To collect data related to learners' perceptions of CS a questionnaire conducted by Kongsom (2009) was adopted. This 24- item questionnaire was designed based on Dornyei's taxonomy (1995) of CSs. Since each two questions investigate learners' attitudes towards one strategy in oral and written performances, the provided answers are more reliable as they were cross checked. Although participants were informed of the format of the questionnaire, to make sure that no misunderstanding arises, the questionnaire was translated in to participants' mother tongue, Persian. Two visual aids in the form of posters were also used for oral and written data elicitation.

\section{Procedure}

In order to meet the goals of the study two sets of data were needed to be collected, one related to the learners' perceptions and the other to the learners' real performances of CSs in oral and written mediums of communication. First participants were asked to fill out the questionnaire and later they were invited to sessions of data elicitation. Data collection procedure for the second set of data was carried out in two main oral and written phases. In the oral phase, in order to divide the task into manageable sections, participants were divided into groups of five for taking part in group discussion sessions. Their performances were sound recorded, and transcribed for further analysis. All the paralinguistic strategies were jotted down at the moment by the researcher. For the written phase, participants were asked to write about a topic at the moment. Bialystok (1990, cited in Bou-Franch, 1994) believes CS taxonomies mostly differ in terminology; however, in the present study Dornyei's taxonomy was used to analyze the data as it is more comprehensive than the previous ones. This taxonomy is presented in table 1. 
TABLE 1.

DORNYEI'S TAXONOMY OF COMMUNICATION STRATEGIES

\begin{tabular}{|c|c|}
\hline \multicolumn{2}{|l|}{ Dornyei's taxonomy of CSs } \\
\hline $\begin{array}{l}\text { Avoidance or Reduction } \\
\text { Strategies }\end{array}$ & \\
\hline 1. Message abandonment & leaving a message unfinished because of language difficulties. \\
\hline 2. Topic avoidance & avoiding topic areas or concepts which pose language difficulties \\
\hline \multicolumn{2}{|l|}{$\begin{array}{l}\text { Achievement or } \\
\text { Compensatory Strategies }\end{array}$} \\
\hline 3. Circumlocution & describing or exemplifying the target object or action (e.g., the thing you open bottles with for corkscrew). \\
\hline 4. Approximation & $\begin{array}{l}\text { using an alternative term which expresses the meaning of the target lexical item as closely as possible (e.g., } \\
\text { ship for sail boat). }\end{array}$ \\
\hline 5. Use of all-purpose words & $\begin{array}{l}\text { extending a general, empty lexical item to contexts where specific words are lacking (e.g., the overuse of thing, } \\
\text { stuff, make, do, as well as using words like thingie, what-do-you-call-it). }\end{array}$ \\
\hline 6. Word-coinage & creating a nonexisting L2 word based on a supposed rule (e.g., vegetarianist for vegetarian). \\
\hline 7. Use of nonlinguistic means & mime, gesture, facial expression, or sound imitation. \\
\hline 8. Literal translation & translating literally a lexical item, an idiom, a compound word or structure from L1 to L2. \\
\hline 9. Foreignizing & $\begin{array}{l}\text { using a L1 word by adjusting it to L2 phonologically (i.e., with L2 pronunciation) and/or morphologically (e.g., } \\
\text { adding to it a L2 suffix). }\end{array}$ \\
\hline 10. Code switching & using a L1 word with L1 pronunciation or a L3 word with L3 pronunciation in L2. \\
\hline 11. Appeal for help & $\begin{array}{l}\text { turning to the conversation partner for help either directly (e.g., What do you call ... ? ?) or indirectly (e.g., rising } \\
\text { intonation, pause, eye contact, puzzled expression). }\end{array}$ \\
\hline \multicolumn{2}{|l|}{$\begin{array}{l}\text { Stalling or Time-gaining } \\
\text { Strategies }\end{array}$} \\
\hline $\begin{array}{l}\text { 12. Use of fillers/hesitation } \\
\text { devices }\end{array}$ & $\begin{array}{l}\text { using filling words or gambits to fill pauses and to gain time to think (e.g., well, now let me see, as a matter of } \\
\text { fact) } \\
\text { Dornyei (1995) }\end{array}$ \\
\hline
\end{tabular}

$$
\text { (Dornyei, 1995, p.58) }
$$

\section{RESULTS}

In the following, learners' perceptions and performances of each CS in oral and written mediums of communication are discussed in details.

1. Message Abandonment

Learners' attitudes towards this strategy was investigated in Questions 14 and 15, answering to which showed that negative attitude prevailed positive and neutral ones in both oral and written mediums.

TABLE 2.

MESSAGE ABANDONMENT

\begin{tabular}{|c|c|c|c|c|c|c|}
\hline \multicolumn{7}{|c|}{ Message Abandonment } \\
\hline & & & & Positive & Neutral & Negative \\
\hline \multirow[t]{7}{*}{ group } & oral & 14 & & 6.00 & 18.00 & 76.00 \\
\hline & & 15 & & 11.00 & 23.00 & 66.00 \\
\hline & & Total & $\mathrm{N}$ & 2 & 2 & 2 \\
\hline & written & 14 & & 5.00 & 22.00 & 73.00 \\
\hline & & 15 & & 7.00 & 22.00 & 71.00 \\
\hline & & Total & $\mathrm{N}$ & 2 & 2 & 2 \\
\hline & Total & & $\mathrm{N}$ & 4 & 4 & 4 \\
\hline
\end{tabular}

In their oral performances, participants used it 50 times which shows that their perceptions and performances were quite different. In written performances, however, this strategy was only for 2 times which indicates that in written performances, by contrast to oral, students' perception and performance are remarkably similar.

2. Topic Avoidance

Questions 10 and 22 investigated participants' attitudes towards topic avoidance; as the frequencies summarized in table3. reveals the fact that participants adopted positive a attitude in oral, while a negative attitude towards this strategy in written communication. 
TABLE 3.

TOPIC AVOIDANCE

\begin{tabular}{|c|c|c|c|c|c|c|}
\hline \multicolumn{7}{|c|}{ Topic Avoidance } \\
\hline & & & & Positive & Neutral & Negative \\
\hline \multirow[t]{7}{*}{ group } & oral & 10 & & 42.00 & 31.00 & 27.00 \\
\hline & & 22 & & 30.00 & 35.00 & 35.00 \\
\hline & & Total & $\mathrm{N}$ & 2 & 2 & 2 \\
\hline & written & 10 & & 35.00 & 18.00 & 32.00 \\
\hline & & 22 & & 28.00 & 14.00 & 44.00 \\
\hline & & Total & $\mathrm{N}$ & 2 & 2 & 2 \\
\hline & Total & & $\mathrm{N}$ & 4 & 4 & 4 \\
\hline
\end{tabular}

In their performances they used this CS in oral performances frequently, 366 times, which was in line with their perception, but 208 time in their written performances which was against their perceptions; therefore, it can be concluded that they were not aware of the frequent use of this CS in their written performances but in oral.

3. Circumlocution

Questions 1 and 20 were set to investigate participants' attitudes towards circumlocution. As the frequencies in table 4. suggest participants adopted a strongly positive attitude towards this strategy.

TABLE 4.

CICUMLOCUTION

\begin{tabular}{|c|c|c|c|c|c|c|}
\hline \multicolumn{7}{|c|}{ Circumlocution } \\
\hline & & & & Positive & Neutral & Negative \\
\hline \multirow[t]{7}{*}{ group } & oral & 1 & & 56.00 & 29.00 & 15.00 \\
\hline & & 20 & & 79.00 & 15.00 & 6.00 \\
\hline & & Total & $\mathrm{N}$ & 2 & 2 & 2 \\
\hline & written & 1 & & 30.00 & 35.00 & 35.00 \\
\hline & & 20 & & 62.00 & 26.00 & 12.00 \\
\hline & & Total & $\mathrm{N}$ & 2 & 2 & 2 \\
\hline & Total & & $\mathrm{N}$ & 4 & 4 & 4 \\
\hline
\end{tabular}

With regards to the performances, however, they did not use this strategy as frequently as they perceived, 18 times in oral and 14 times in written. It can be concluded that students did not use the strategy as much as they perceived.

4. Approximation

Answers to questions 2 and 21 (Table 5) indicate that positive attitude was prevailing to negative and neutral attitudes towards approximation in oral and written mediums of communication.

TABLE 5.

APPROXIMATION

\begin{tabular}{|c|c|c|c|c|c|c|}
\hline \multicolumn{7}{|c|}{ Approximation } \\
\hline & & & & Positive & Neutral & Negative \\
\hline \multirow[t]{7}{*}{ group } & oral & 2 & & 51.00 & 29.00 & 20.00 \\
\hline & & 21 & & 79.00 & 15.00 & 6.00 \\
\hline & & Total & $\mathrm{N}$ & 2 & 2 & 2 \\
\hline & written & 2 & & 41.00 & 33.00 & 26.00 \\
\hline & & 21 & & 60.00 & 24.00 & 10.00 \\
\hline & & Total & $\mathrm{N}$ & 2 & 2 & 2 \\
\hline & Total & & $\mathrm{N}$ & 4 & 4 & 4 \\
\hline
\end{tabular}

In both oral and written performances participants used this strategy frequently too, 176 and 137 times respectively, which shows that their perceptions and performances of the use of this CS are well coordinated.

5. Use of All Purpose Words

Questions 16 and 3 were designed to investigate learners' perceptions of the use of all purpose words in communication. As shown in table 6. Learners adopted a negative attitude towards this strategy in both oral and written mediums of communication. 
TABLE 6.

USE OF ALL PURPOSE WORDS

\begin{tabular}{|c|c|c|c|c|c|c|}
\hline \multicolumn{7}{|c|}{ Use of All-purpose Words } \\
\hline & & & & Positive & Neutral & Negative \\
\hline \multirow[t]{7}{*}{ group } & oral & 3 & & 56.00 & 25.00 & 19.00 \\
\hline & & 16 & & 13.00 & 31.00 & 54.00 \\
\hline & & Total & $\mathrm{N}$ & 2 & 2 & 2 \\
\hline & written & 3 & & 44.00 & 27.00 & 29.00 \\
\hline & & 16 & & 8.00 & 28.00 & 64.00 \\
\hline & & Total & $\mathrm{N}$ & 2 & 2 & 2 \\
\hline & Total & & $\mathrm{N}$ & 4 & 4 & 4 \\
\hline
\end{tabular}

However, participants did not perform as they perceived in oral performances; they used this strategy 57 times which reveals that this CS was effective in preventing communication breakdowns. In written performances, on the other hand, they used this strategy 10 times which shows that their negative attitude was not completely manifested in their written performances.

6. Word Coinage

As reported in Table7. with regards to word coinage, students insisted that they never do it in their communication, and negative attitudes towards this strategy strongly prevails positive and neutral attitudes.

TABLE 7. WORD COINAGE

\begin{tabular}{|c|c|c|c|c|c|c|}
\hline \multicolumn{7}{|c|}{ Word Coinage } \\
\hline & & & & Positive & Neutral & Negative \\
\hline \multirow[t]{7}{*}{ group } & oral & 4 & & 111.00 & 15.00 & 74.00 \\
\hline & & 23 & & 10.00 & 17.00 & 73.00 \\
\hline & & Total & $\mathrm{N}$ & 2 & 2 & 2 \\
\hline & written & 4 & & 7.00 & 12.00 & 81.00 \\
\hline & & 23 & & 5.00 & 22.00 & 73.00 \\
\hline & & Total & $\mathrm{N}$ & 2 & 2 & 2 \\
\hline & Total & & $\mathrm{N}$ & 4 & 4 & 4 \\
\hline
\end{tabular}

However this strategy was observed 10 times in the performances, 5 times in each medium. It can be concluded that students negative attitudes towards this CS, to some extent, was manifested in their performances and they used it whenever there were no other ways to save the communication.

7. Use of Nonlinguistic Means

With regard to this strategy, it was observed that negative attitudes prevails positive and neutral attitudes. The answers to questions 5 and 12 are summarized in table 8 .

TABLE8.

USE OF NONLIGUISTIC MEANS

\begin{tabular}{|c|c|c|c|c|c|c|}
\hline \multicolumn{7}{|c|}{ Use of Nonlinguistic Mean } \\
\hline & & & & Positive & Neutral & Negative \\
\hline \multirow[t]{4}{*}{ group } & oral & 5 & & 34.00 & 23.00 & 43.00 \\
\hline & & 12 & & 35.00 & 32.00 & 33.00 \\
\hline & & Total & $\mathrm{N}$ & 2 & 2 & 2 \\
\hline & Tota & & $\mathrm{N}$ & 2 & 2 & 2 \\
\hline
\end{tabular}

However, in their performances they used it 52 times which shows that their perception and performance were completely distinct.

8. Literal Translation

Participants perceived literal translation as a useless one and strongly insisted to show negative attitudes towards this $\mathrm{CS}$, the frequencies related to questions 6 and 17 presented in table9. support this fact. 
TABLE 9.

LITERAL TRANSLATION

\begin{tabular}{|c|c|c|c|c|c|c|}
\hline \multicolumn{7}{|c|}{ Literal Translation } \\
\hline & & & & Positive & Neutral & Negative \\
\hline \multirow[t]{7}{*}{ group } & oral & 6 & & 20.00 & 38.00 & 41.00 \\
\hline & & 17 & & 9.00 & 44.00 & 47.00 \\
\hline & & Total & $\mathrm{N}$ & 2 & 2 & 2 \\
\hline & written & 6 & & 18.00 & 28.00 & 54.00 \\
\hline & & 17 & & 9.00 & 34.00 & 57.00 \\
\hline & & Total & $\mathrm{N}$ & 2 & 2 & 2 \\
\hline & Total & & $\mathrm{N}$ & 4 & 4 & 4 \\
\hline
\end{tabular}

The performances, however, were completely different from perceptions. Learners used this strategy constantly in both oral and written performances, 250 and 202 times respectively. It is concluded that learners' perception and performance were quite distinct.

9. Foreignizing

Questions 7 and 24 were set to investigate learners' attitudes towards foreignizing. As the figures in table 10. suggest negative attitudes highly prevails positive and neutral attitudes towards this CS.

TABLE10.

FOREIGNIZING

\begin{tabular}{|c|c|c|c|c|c|c|}
\hline \multicolumn{7}{|c|}{ Foreignizing } \\
\hline & & & & Positive & Neutral & Negative \\
\hline \multirow[t]{4}{*}{ group } & oral & 7 & & 7.00 & 5.00 & 88.00 \\
\hline & & 24 & & 6.00 & 7.00 & 87.00 \\
\hline & & Total & $\mathrm{N}$ & 2 & 2 & 2 \\
\hline & Total & & $\mathrm{N}$ & 2 & 2 & 2 \\
\hline
\end{tabular}

Participants' perception is met in their real performances, since they used this strategy just for 2 times.

10. Code Switching

The frequencies presented in table 11, regarding the answers to questions 8 and 25, show that participants strongly disagree with the use of this CS as a useful one and adopted a negative attitude towards it.

TABLE 11

CODE SWITCHING

\begin{tabular}{|c|c|c|c|c|c|c|}
\hline \multicolumn{7}{|c|}{ Code Switching } \\
\hline & & & & Positive & Neutral & Negative \\
\hline \multirow[t]{7}{*}{ group } & oral & 8 & & 24.00 & 19.00 & 57.00 \\
\hline & & 18 & & 9.00 & 35.00 & 56.00 \\
\hline & & Total & $\mathrm{N}$ & 2 & 2 & 2 \\
\hline & written & 8 & & 12.00 & 15.00 & 73.00 \\
\hline & & 18 & & 11.00 & 18.00 & 71.00 \\
\hline & & Total & $\mathrm{N}$ & 2 & 2 & 2 \\
\hline & Total & & $\mathrm{N}$ & 4 & 4 & 4 \\
\hline
\end{tabular}

In their performances, however, they used this CS 34 times in oral and 11 times in written performances, which shows that their performances are different from their perception.

11. Appeal for Help

Generally participants adopted a positive attitude towards this strategy both in oral and written performances. The frequencies related to questions 9 and 19 are presented in table 12 . 
TABLE 12.

APPEAL FOR HELP

\begin{tabular}{|c|c|c|c|c|c|c|}
\hline \multicolumn{7}{|c|}{ Appeal For Help } \\
\hline & & & & Positive & Neutral & Negative \\
\hline \multirow[t]{7}{*}{ group } & oral & 9 & & 53.00 & 30.00 & 17.00 \\
\hline & & 19 & & 49.00 & 35.00 & 16.00 \\
\hline & & Total & $\mathrm{N}$ & 2 & 2 & 2 \\
\hline & written & 9 & & 42.00 & 42.00 & 16.00 \\
\hline & & 19 & & 40.00 & 38.00 & 22.00 \\
\hline & & Total & $\mathrm{N}$ & 2 & 2 & 2 \\
\hline & Total & & $\mathrm{N}$ & 4 & 4 & 4 \\
\hline
\end{tabular}

Participants used this CS 31 times in their performances which shows that they performed as they perceived. It should be noted that since taking this strategy in to account in written performances was not manageable, students were not allowed to ask any questions during the process of written performance and this CS was only examined in their oral performances.

12. Time Gaining

Learners' attitudes towards this CS were investigated in questions 11 and 13, in which they adopted a positive attitude towards it (table 13).

TABLE 13

TIME GAINING

\begin{tabular}{|c|c|c|c|c|c|c|}
\hline \multicolumn{7}{|c|}{ Time Gaining } \\
\hline & & & & Positive & Neutral & Negative \\
\hline \multirow[t]{4}{*}{ group } & oral & 11 & & 50.00 & 37.00 & 13.00 \\
\hline & & 13 & & 42.00 & 41.00 & 17.00 \\
\hline & & Total & $\mathrm{N}$ & 2 & 2 & 2 \\
\hline & Total & & $\mathrm{N}$ & 2 & 2 & 2 \\
\hline
\end{tabular}

Participants used this strategy 326 times in their oral performances which shows that their perception and performance are coordinated. since adopting this strategy was impossible to be coded in their written performances, the oral performances were only examined

Generally speaking, negative attitude was prevailing to positive and neutral attitudes; however, learners used CSs frequently in their performances. It indicates that their perceptions and performances are not in line in the use of CSs. Comparing answers in two sections of the questionnaire, i.e. oral and written mediums, the researchers found that learners thought CSs are more helpful in oral performances rather than written ones, which was coordinated with their real performances as CSs were used more frequently in oral performances rather than written ones.

\section{DISCUSSION AND CONCLUSION}

Although the optimal goal of all language learners is to communicate effectively, after years of study the problem still exists and they have some problems in their communications, both in oral and written performances. The problem exists even among university students who have chosen English as their field of study. The reason of such failure is beyond the scope of this study, however, what has been investigated here is how learners think they can overcome these inabilities in communication, and to what extent their perceptions and real performances coordinate; in fact, in this study the researcher was after finding out if students are aware of their use of CSs. As mentioned previously some reported attitudes were not in line with performances which can be discussed through various perspectives.

Generally speaking students showed negative attitudes towards the use of CSs; however, they used them frequently in their performances. This can be discussed from different linguistic, sociolinguitic, and psycholonguistic perspectives. The first and the most important matter is that students are not aware of their frequent use of CSs which shows they are not aware of their language deficiencies or they may just resist accepting their deficiencies.

Although negative attitude prevailed positive and neutral attitudes, participants claimed that CSs are more helpful in oral performances rather than written ones. Faerch and Kasper (1980) held that CSs can be defined based on two main criteria: problem orientedness and consciousness. Considering the former CSs are used when learners come across some problems in communication unable to solve, while the latter implies that the learners are already aware of the problems in the course of communication so they will try to solve the problem; therefore, CSs can be defined as conscious plans to be used for solving communication problems. Hence, based on the findings of this study, it can be concluded that learners are either aware of the fact that keeping oral communication channel open is more difficult than written, and they are generally aware of the basic differences between oral and written mediums of communication, or 
learners admitted that they have more problems in oral communication rather than written, in fact they believed that they encounter deficiencies in oral performances more than written ones.

Findings of this study are of great significance for language teachers and material designers. Using CSs, students will not feel any need to improve their knowledge of language, because they can keep communication channel open by the help of these strategies. Additionally, they may help learners remain in a conversation and so provide the learners with more input, more opportunities for checking and validating their hypotheses, and consequently, more chances to develop their interlanguage system (Mariani, 2010); therefore, if teachers find out more about the strategies, they will find more about the problem areas to be catered for in the classroom. On the other hands teachers can teach students how to use these CSs without producing erroneous sentences. Material designers, still, will find the study useful in the process of material preparation. They can find problem areas to put more emphasis on, and also provide opportunities for students to learn how to use strategies effectively in their communication.

Any research has some limitations and the present study is no exception. There were no classification based on proficiency levels, and also there were no interviews to find out more about learners perception or think aloud sessions to find what was really happened in the learners' minds during the course of performance. Taking such variables in to considerations will surely provide a more comprehensive view to CSs.

\section{REFERENCES}

[1] Baker, C. (1992). Attitude and Language. United Kingdom: Multilingual Maters.

[2] Barkhuizen, G.P. (1998). Discovering Learners' Perceptions of ESL Classroom Teaching/Learning Activities in South African Context. TESOL Quarterly, 32.1, 85-108.

[3] Bou-Franch, P. (1994).Communication Strategies and Topic Sequences in the Conversational Discourse of Spanish Learners of English. Stylistica, 2.3,153-162.

[4] Corder, P. (1981). Error Analysis and Interlanguage. UK: Oxford University Press

[5] Dornyei, Z. (1995), On the Teachability of Communication Strategies. TESOL Quarterly. 29.1, 55-85.

[6] Ellis, R. (1984). Communication Strategies and the Evaluation of Communicative Performance. ELT Journal, 38.1, 39-44.

[7] Faerch,C and Kasper,G. (1980) Processes and Strategies in Foreign Language Learning and Communication. Interlanguage Studies Bulletin Utrecht, 5(1), 47-118.

[8] Gabillon, Z. (2005). L2 Learner's Beliefs: An Overview. An International Journal for Language and Education Studies. 3.2, 233-260.

[9] Jamshidnejad, A. (2011). Learners' Performance in and Beliefs about Problematic L2 Oral Communication in an EFL Context: A Qualitative analysis. The Iranian EFL Journal, 7 (5). 20-42.

[10] Kongsom, T (2009). The Effect of Teaching Communicative Strategies to Thai Learners of English. Ph.D. dissertation, University of Southampton, faculty of Law, Art, and Social sciences Retrieved from: http://eprints.soton.ac.uk/69653/1.hasCoversheetVersion/Tiwaporn_Kongsom_24_11_09.pdf phd thesis. (accessed 29/11/2011)

[11] Mariani, L. (2010). Communication strategies: Learning and teaching how to manage oral interaction. Italy: Learning PathsTante Vie Per Imparare. in soshami \& hamoon tylandie

[12] Puffer, Ch. D. (2006). Questions as Strategies to Encourage Speaking in Content and Language Inegrated Classrooms. In In Uso-Juan,E., \& Martinez- Flor, A. (eds). Current trends in the Development and Teaching of the Four Language Skills (). Berlin, New York: Mount de Gruyter, 187-214.

[13] Richards, J.C., \& Schmidt, R. (2002). Longman Dictionary of language teaching and applied linguistics. Malaysia: Pearson Educated Limited

[14] Saidat, A.M. (2010). Language Attitude: The Case of Jordan. International Journal of Academic Research, 2.6, $235-243$.

[15] Selinker, L. (1972). Interlangauge. IRAL, 10.3, 219-231.

[16] Silva, T. (1993). Toward and Understanding of the Distinct Nature of L2 Writing. TESOL Quarterly, 27.4, 657-677.

[17] Zheng, Z. (2004). Communicative competence and strategic competence. Sino-US English Teaching, 1.10, 70-75.

[18] Wei, L. (2011). Communicative Strategies in Second Language Acquisition: A Study of Chinese English Learners' Attitude and Reported Frequency of Communicative Strategies. http://www.essays.se/essay/8a4ee7c802/ (accessed 28/10/2011)

[19] Williams, M.,\& Burden,R. (1997). psychology for language teachers: a social contrastive approach. Cambridge: Cambridge University Press.

Asa Moattarian is currently an MA student in Applied Linguistics at Sheikhbahaee University, Isfahan, Iran. She Received her BA. degree in English translation from Khhorasgan Azad University, Isfahan, Iran (2010). Her main research areas of interest are: Second Language Acquisition, Interlanguage, and Foreign Language Teaching. 